\title{
Application of Free Structural Model to Hydrocarbon Production Optimization in X Field, Niger Delta.
}

\author{
Nwankwo, C.N and Anyanwu, J \\ Department of Physics, University of Port Harcourt
}

\begin{abstract}
This study attempts to optimize hydrocarbon production of an oil Field in Niger Delta through an uncertainty free hydrocarbon reservoir modelling. Four well logs and seismic data of 5500 to 5900 inline and 1480 to 1720Xline range were used to build a structural model and reduce uncertainties from the delineated reservoirs. All the four wells have reservoirs of interest as delineated from well logs based on sand formation resistivity values and porosity information. From the logs interpretation hydrocarbon prolific sand of each well was correlated as reservoirs $D$ and $F$. The depth and the lateral extent of the reservoirs were secured by tying the well 2 to inline of the seismic. Faults were interpreted along the fault trends using fault sticks. Out of many interpreted faults only F7, F8, F10 and F2O cut across the delineated reservoirs. The horizons of reservoirs D and $F$ were also interpreted and the isochronal maps generated. Time to Depth conversion using the T-Z curve gave rise to the depth maps, upon which the reservoir tops were delineated. To generate the structural model, the faults which cut across the reservoir were modeled and pillar gridded to have 10000 cells with each one having a petrophysical property. This formed the skeleton of the reservoir which was layered on the depth map thereby building the structural model. Furthermore, different hydraulic zones (stratigraphic intervals) of the structural model were established. Zonation of the reservoirs enhanced the sensitivity of the petrophysical properties in every stratigraphic interval of the structural model. The structural style showed fault enclosed anticlinal structure while the grid cells from the skeleton of the structural model, depicts the top, middle, and the base of the reservoir.
\end{abstract}

Keywords: Seismic interpretation, Faults model, Pillar gridding, reservoir, structure, hydrocarbon.

\section{Introduction}

Niger Delta Nigeria is among the hydrocarbon prolific basins in the world (Alao et al., 2013). The area lies on Longitude $3^{\circ} \mathrm{E}$ to $9^{\circ} \mathrm{E}$ and Latitude $4^{\circ} 3^{\prime} \mathrm{N}$ to $5^{\circ} 2^{\prime} \mathrm{N}$ (Ekine and Ibe, 2013) and forms part of the coastal plain of southern Nigeria. This basin has complex structural features which when not properly delineated, may hamper optimum hydrocarbon production.

Along the stratigraphic intervals of the delta, hydrocarbon is chiefly produced from sandstone and unconsolidated sands of the Agbada Formation (Emujakporue and Ngwueke 2013). Subsurface configurations must be understood in detail to effectively delineate the structures that can trap hydrocarbon. This is because hydrocarbons are generally accumulated in geometric arrangement of rocks known as traps in the subsurface (Morgan and Dow, 1994). These traps can be structural (Faults and Folds), stratigraphic or both. Due to heterogeneous nature of hydrocarbon traps, reservoirs are sometimes compartmentalized (Jolley et al., 2010). In the Niger Delta, hydrocarbon bearing fields are characterized by multiple heterogeneous reservoirs geometry stacked over intervals of 10,000 feet thickness. The heterogeneities which occur at all scales from pore scale to major reservoir units result to a spatial variation in the reservoir properties. This constitutes a problem during further production planning if not properly handled.

According to Israel et al. (2006), fault surfaces are common subterranean structures which are associated with displacement or offset of subsurface layer. They are known to be essential for hydrocarbon exploration since they are associated with hydrocarbon accumulation and flow paths. For the purpose of mapping geologic or complex geologic structures of an area, 3-D seismic data is often used. The most reliable component of hydrocarbon structural model is done by identifying, locating, extracting and modelling the fault surfaces from the realized 3-D seismic data. Extractions of fault surfaces from seismic data have been known to be a qualitative technique and therefore require a careful human interpretation (Israel et al., 2006).

A specific volume of the subsurface which incorporates all the geologic characteristics of the reservoir can be modelled to figure out the structural style and the heterogeneous geometry of the reservoir. The objective of this study is to build the reservoir structural model of $\mathrm{X}$ oil field that will give a better understanding of the subsurface. Such model must depict the structural pattern and the geometric heterogeneity of the reservoir that will help inform the wells placement. 


\section{Geology of the Niger Delta}

The Niger Delta is perhaps the most important sedimentary basin in sub-Sahara Africa for petroleum production. It is a prograding depositional complex within the Cenozoic formation of Southern Nigeria.The area of Niger Delta Basin is about 75,000 square kilometres. It extends from the Calabar flank and the Abakaliki trough in Eastern Nigeria to the Benin flank in the west and opens to the Atlantic Ocean in the south (Fig. 1). The Delta extends beyond the gulf of Guinea as an extension from the Benue Trough and Anambra Basin provinces. The delta complex merges westwards across the Okitipupa high into the Dahomey embayment. To the southeast, the important line of volcanic rocks comprising the Cameroon volcanic zone (mountains) and Guinea ridge form the other margin (Allen, 1965;Oomkens, 1974).

Three stratigraphic sequenceshave been identified in the Niger Delta: the Benin Formation, Agbada Formation and Akata Formation. Reservoir rocks are predominant in Agbada Formation. The features of this formation are dependent on its depositional environment and depth of burial. These reservoir rocks have the ability to exchange fluid as the original water in the trap is displaced by hydrocarbon. Identified reservoir rocks in Niger Delta are of Eocene and Pliocene age. According to Doust and Omatsola (1990), thicker reservoirs are

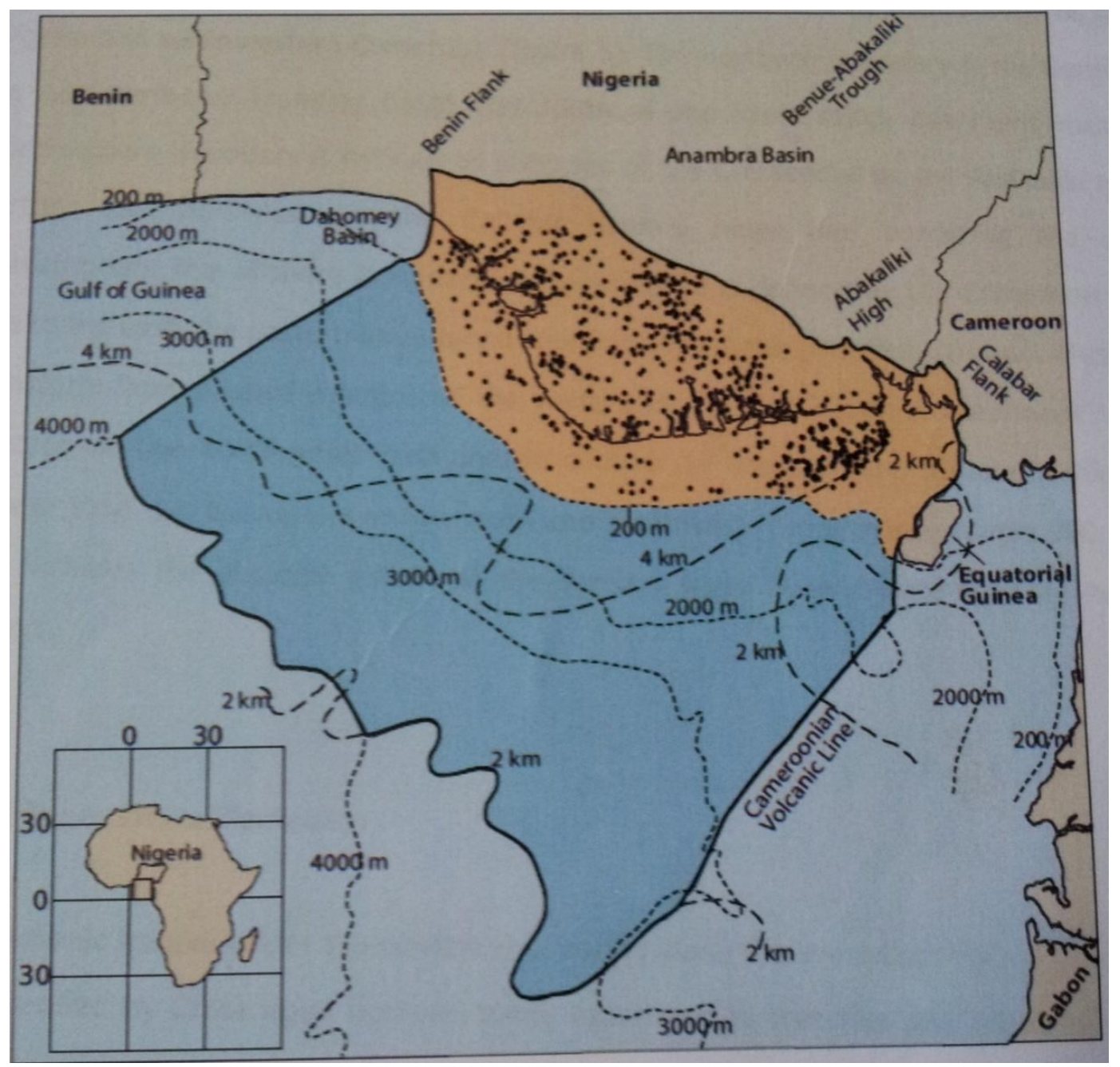

Fig. 1: The Location Map of Niger Delta Showing the Offshore Limit and the Surrounding Sedimentary Basins (Petroconsultants, 1996a)

probably, composite bodies of stacked channels. Single reservoirs can have vertical and/or lateral variation in porosity and permeability. These variations could be caused by primary depositional process or by secondary diagenetic or deformational effects thereby leading to hydrocarbon saturated but unproductive waste zone (Biddle and Wielchowsky, 1994). Transiton over some distance between reservoirs can also result from variation in porosity and permeability. Lateral variation of reservoir thickness is caused by down throw growth of fault. The reservoir fluvial sandstone are more coarse than the delta while point bars fine upward and barrier bars have the best grain sorting. Potential reservoirs are built on the outside part of the delta complex by deep sea channel sands, low stand sand bodies and proximal turbidites. 


\section{Materials and Methods}

Data used for this study were given by Nigerian Agip Oil Company Limited, Port Harcourt. The nature of this research necessitated the use of PETREL software. The data comprised of digitized composite well logs in LAS format from four wells (Fig. 2), 3-D seismic (SEG Y) and checkshot data. The seismic data was used in establishing structural interpretation and model. It provides a wide field of view of lateral extent of the study area and hence was used to generate seismic volume. The horizons and the faulted areas of the study were conspicuous in the processed seismic data. The seismic lines were inlines which were shot parallel to the strike direction and cross-lines shot parallel to the dip direction. Well log data gave greater depth resolution than the seismic data. With the well log data, it was possible to delineate our potential reservoirs.

The composite well $\log$ data comprised gamma ray log, resistivity log, sonic, density and neutron porosity logs. Compressional wave velocity which when multiplied with density gives acoustic impedance was generated by evaluating the inverse of the interval transit times of the sonic logs. The reflectivity of the log was also generated from the acoustic impedance.

Hydrocarbon reservoirs are porous and permeable sand beds. For reservoirs areas of interest, resistivity $\log$ from each well was used to delineate the water bearing sand from hydrocarbon sand. High resistivity value indicates hydrocarbon accumulation. Therefore reservoirs D and F (Fig. 3) were delineated using GR and resistivity logs. Correlation was done to incorporate all the reservoirs of the wells..

The interpreted lithofacies from well logs were matched against reflection events from seismic sections. Primarily, the amplitude and continuity of reflection on the seismic sections were the bases for choosing reflection events. Prior to structural interpretation, synthetic seismogram was generated using checkshots data from well 2. The synthetic data was then tied to the seismic (Fig. 4). This tie was the first stage in picking the zero phases which corresponded to the tops of the sands for interpretation. Horizons within the well logs that show hydrocarbon prospect were selected for mapping. The depths of these horizons were converted to two-way travel times using the time-depth relation curve (Fig. 5).

\section{Structural Interpretation}

The vertical discontinuities (fault traces) were traced on the inline of the seismic section. Interpretation of faults was done by digitizing the fault trends using the fault sticks (Fig. 6). This was the bases upon which fault skeleton was generated. Many faults were interpreted including five major faults, namely, F1, F2, F3, F7 and F8 (Fig. 5). F1, F2, F3 and F8 trend northwest and southeast while F7 trends the northeast and southwest directions. Other minor faults are F20, F10 and F6.

Picking of the lithofacies was done on the cross-line using the intersection of the inline and xline since xline runs east-west. The horizons were located on either side of the faults (Fig. 7, 8).

Contour map which shows two way time to a reflector as picked on the seismic section was depth matched using the average velocity information obtained from sonic log data and the check shot. The predicted average velocity away from the wells was employed to develop the time average velocity map which was used to convert the reservoir tops to depths. This is to say the time structural maps (Figs. 9a and 9b) were used to generate depth structural map of various reservoirs using the velocity model (Figs. 10a, 10b).

\section{Structural Model}

The three stages in structural model which are; fault modeling, pillar gridding and zonation are often interwoven. Since faults result to lithologic deformation, opposite sides of faults may be homogeneous or heterogeneous in thickness. The similarity or discrepancy in opposite sides of fault is always related to the faulting pattern and the depositional environment. A proper delineation of seal which can prevent flow was done through fault modelling. According to Christopher and Dario (2010), fault modelling is considered as the most essential structural modelling process due to their great impact on reservoir compartmentalization. Fluid flow is dependent on the accuracy of fault modelling.

The faults have been interpreted in the structural seismic interpretation using fault sticks. Then the model was done using the key pillar system. The key pillars were vertical, linear, listric or curve lines described by two, three or five shaped point. Many key pillars were joined together and distributed evenly according to the shape points which define the fault plane. The key pillars were mounted along all the faults to be incorporated in the reservoir model. The fault modelling therefore forms the basis upon which 3-D grid was generated. Within the grid line, there were breaks which were as a result of faults. A total of four fault skeletons were generated (Fig.11).

Pillar gridding the modelled faults transformed them into 2-D window where the modelled faults changed to nods along each fault plane (Fig. 12). An external grid boundary was created around the fault model, and grids were added to generate 10,000 cells (Fig.13). Each of the grid cells has a single rock type; one value of porosity, one value of water saturation and permeability. This preserves small features from well logs and seismic data. Structural model of high resolution grids results to spatial complexity of the reservoir, while 
low resolution grids (few cells) bring about structural model with less complexity which makes it easy to be worked on. Having pillar gridded the modelled fault, structural models of the delineated reservoirs were then generated using the depth map (Fig. 14).

The sensitivity of the static parameters in the structural model was enhanced by dividing the reservoir into their various geologic zones (Fig. 15), witheach zone having similar petrophysical properties. Zonation during vertical layering of the structural model integrates the seismic and well log data and divides the structural model and the correlated well into different flow zones (Figs. 15; 16). This was estimated on the stratigraphic interval and each horizon used to make zones defined a stratigraphic interval. The vertical offset of the faults were delimited by a vertical layering while fine scale grids generated from layering define the vertical variation within each geologic zone.

To distinguish hydrocarbon from water in the delineated reservoirs, resistivity and density logs were used. The sections of the reservoirs with low density and high resistivity signature were picked as hydrocarbon while that with high density and low resistivity is water.

\section{Results and Discussion}

A representative reservoir model based on geology and petrophysical properties has been developed using 3-D seismic data and well log. Lateral extent of reservoirs D and F were delineated using seismic data while their depth resolution depended on the well logs.

The lithology of the field consists of sand, shale and sand/shale intercalation. Similar formations were not delineated at the same depth across the wells due to faulted regions of the lithology. In reservoir D (Fig. 3), some of the sand formation in wells 2 and 4 pinched out. This was evidencedby high fault throw. In reservoir F the pinching out of the sand formation in well 2 was due to a greater fault throw unlike wells 1,3 and 4 which have almost the same sand formation (Fig. 3). The correlated wells delineated the tops and the bases of reservoir $\mathrm{D}$ and $\mathrm{F}$ as shown in Table 1.

Table 1: The delineated depths of reservoir D and F

\begin{tabular}{|l|l|l|l|l|l|l|}
\hline Well & \multicolumn{3}{|c|}{ Reservoir D } & \multicolumn{3}{c|}{ Reservoir F } \\
\hline & Top $(\mathrm{m})$ & Bases $(\mathrm{m})$ & Thickness $(\mathrm{m})$ & Top $(\mathrm{m})$ & Base $(\mathrm{m})$ & Thickness $(\mathrm{m})$ \\
\hline 1 & 3562.44 & 3618.26 & 55.82 & 3740.7 & 3851.2 & 110.5 \\
2 & 3532.02 & 3593.9 & 61.78 & 3717.97 & 3832.6 & 114.63 \\
3 & 3492.9 & 3621.9 & 129 & 3756.09 & 3856.0 & 99.99 \\
4 & 3531.66 & 3672.8 & 141.14 & 3791.4 & 3890.8 & 99.4 \\
\hline
\end{tabular}

The ability to figure out the structural heterogeneity of this oil field started from the qualitative structural interpretation in which structural modelling was based on. Vertical discontinuity as seen in seismic section (Fig. 4) could be due to fault traces. The reflectivity of the seismic section was clear although it decreases with time. Chaotic region was observed between 3.2 to 3.8 seconds within which seismic amplitude became very low causing internal blurred lateral reflection (Fig. 5). At very low amplitude of the seismic reflection, the major faults become ambiguous.Fractured deposits due to overpressure were interpreted as the low amplitude reflection zones with uneven to sudden or blurred gradational boundaries.

From the interpreted faults (Fig. 6), F7, F8, F3 and F7 trend northwest and southeast while F8 trends northeast and southwest. The interpreted horizon passes through the well tops of reservoir D and F (Fig. 7).

On the time map of reservoir D (Fig. 9a), wells 1 and 3 were located between $2850 \mathrm{~ms}$ and $2820 \mathrm{~ms}$ while wells 4 and 2 were close to $2820 \mathrm{~ms}$. Reservoir F had wells 1 and 2 between $2970 \mathrm{~ms}$ and 2940 ms while wells 3 and 4 were below $2940 \mathrm{~ms}$ (Fig. 9b). Looking at the depth map of reservoir D (Fig. 10a), the tops of wells 1 and 2 were located below 3570m, wells 2 and 3 were below $3540 \mathrm{~m}$ while the top of well 4 is below $3510 \mathrm{~m}$. For reservoir F, wells 1 and 3 are close to $3550 \mathrm{~m}$ but wells 4 and 2 are below $3800 \mathrm{~m}$ (Fig. 8b). The faults in these depth maps were enclosed by anticline.

Faults brought about the heterogeneity of reservoirs D and F structural models. Lateral variation in the thickness of reservoirs resulted from down throw growth of faults. The depth maps showed that only four faults cut across the reservoirs (Fig. 13), forming their geometrical structure. The key pillars of the faults were vertical, linear and listiric or curve lines. The pillar gridded faults produced the architecture of the reservoir (Fig. 13) with 10000 cells which are significant to flow model. To every cell, there was one petrophysical property. The structural model of reservoir D and F (Fig. 14) stacked together describes the reservoirs layers and spatial heterogeneity.

Since sand/shale intercalation can form static or dynamic seal, the reservoirs were divided into different flow zones (Fig. 15; 16). The compartmentalized reservoirs can prevent or cause a drop in fluid flow. The hydraulic zones for the reservoirs as obtained from figure 16 are shown on Table 2. According to Jolly et al. (2010), the boundaries of these delineated zone resulted from geologic factor. The outstanding uncertainties which have been successfully removed to optimize production were the compartments of the reservoirs. The 
hydraulic units in various zones were caused by juxtaposition between reservoir and none reservoir rocks across faults (Ajakaiye and Bally, 2002; Ainsworth, 2006). Between zones, transitions are caused by variations in porosity and permeability.

Table 2. Hydraulic zones of reservoir D and F

\begin{tabular}{|l|l|l|l|l|}
\hline Reservoir/Zones & Well 1 & Well 2 & Well 3 & Well 4 \\
\hline D/Zones & 4 & 5 & 7 & 7 \\
F/Zones & 5 & 5 & 5 & 5 \\
\hline
\end{tabular}

The flow zones are employed to determine the hydrostatic performance and the heterogeneity of the reservoir from small to large scale thereby reducing uncertainty.

\section{Conclusion}

The attempt to build the architecture of a hydrocarbon prolific area has proved that since the Niger Delta oil fields have multiple reservoirs stalked together, their extensional heterogeneity can only be delineated by an accurate modelling of the subsurface.

Less uncertainty in the structural style was achieved by modelling and pillar gridding with only faults that cut across the reservoir. This determines the geometry of the reservoirs. The structural style showed fault enclosed anticlinal structure. The modelled depth map of the two considered reservoirshas revealed that well placements were not very close to the faults. However the grid cells from the skeleton of the structural model, depicts the top, middle, and the base of the reservoir. Different geologic zones have different hydrocarbon prolific capacity and this is pertinent to their hydraulic performance.

\section{Acknowledgement}

The Authors are grateful to Nigerian Agip Oil Company Limited Port Harcourt, for providing the data used in this study.

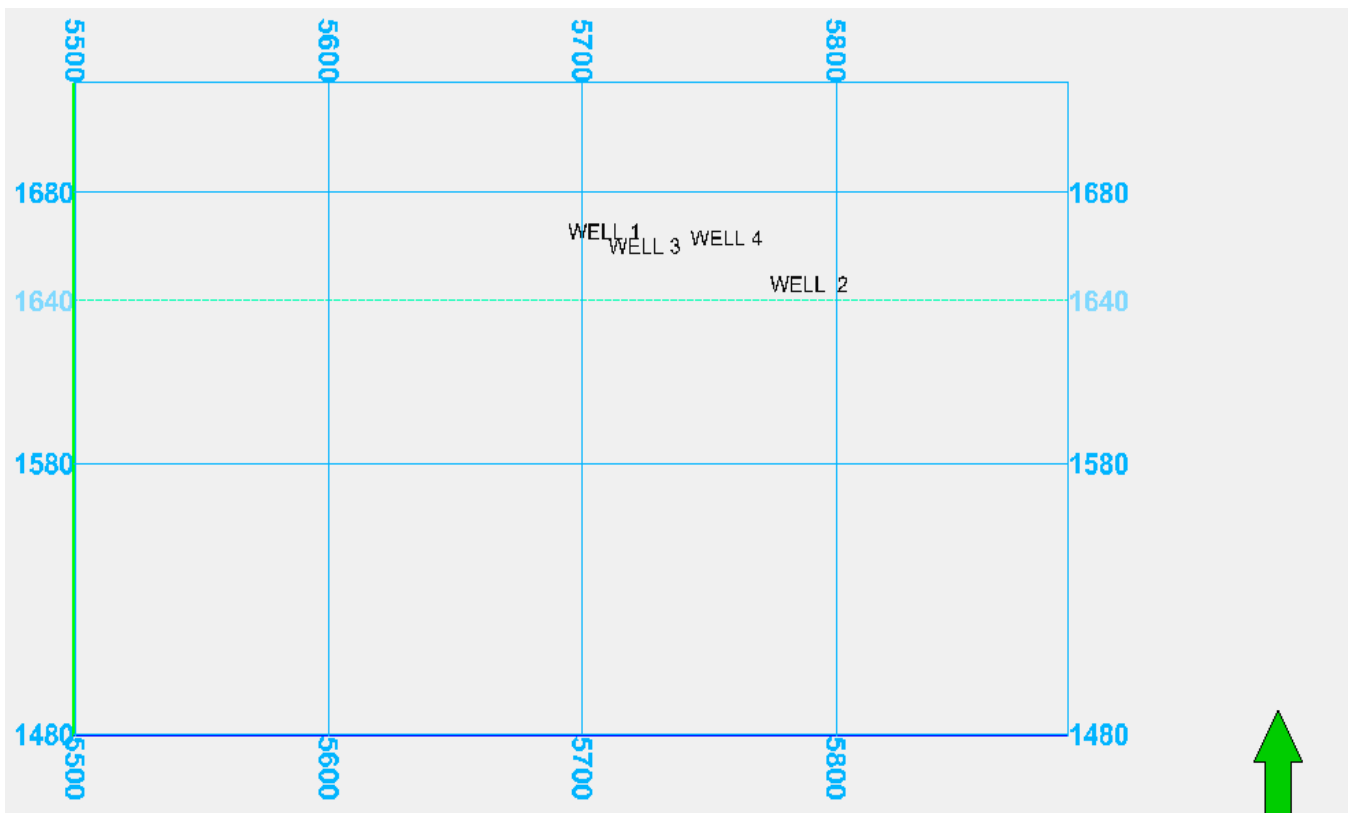

Fig. 2: X Oil field base map with the seismic header of Inline range: 5500 to 5900, Xline range: 1480 to 1720 , Inline/Xline interval: 25m. Wavelet type: Zero phase and Polarity: SEG Reverse. 
Application of Free Structural Model to Hydrocarbon Production Optimization in X Field, Niger.......



Fig. 3: Well correlation.



Fig. 4: Well-to-seismic Tie of D and F 


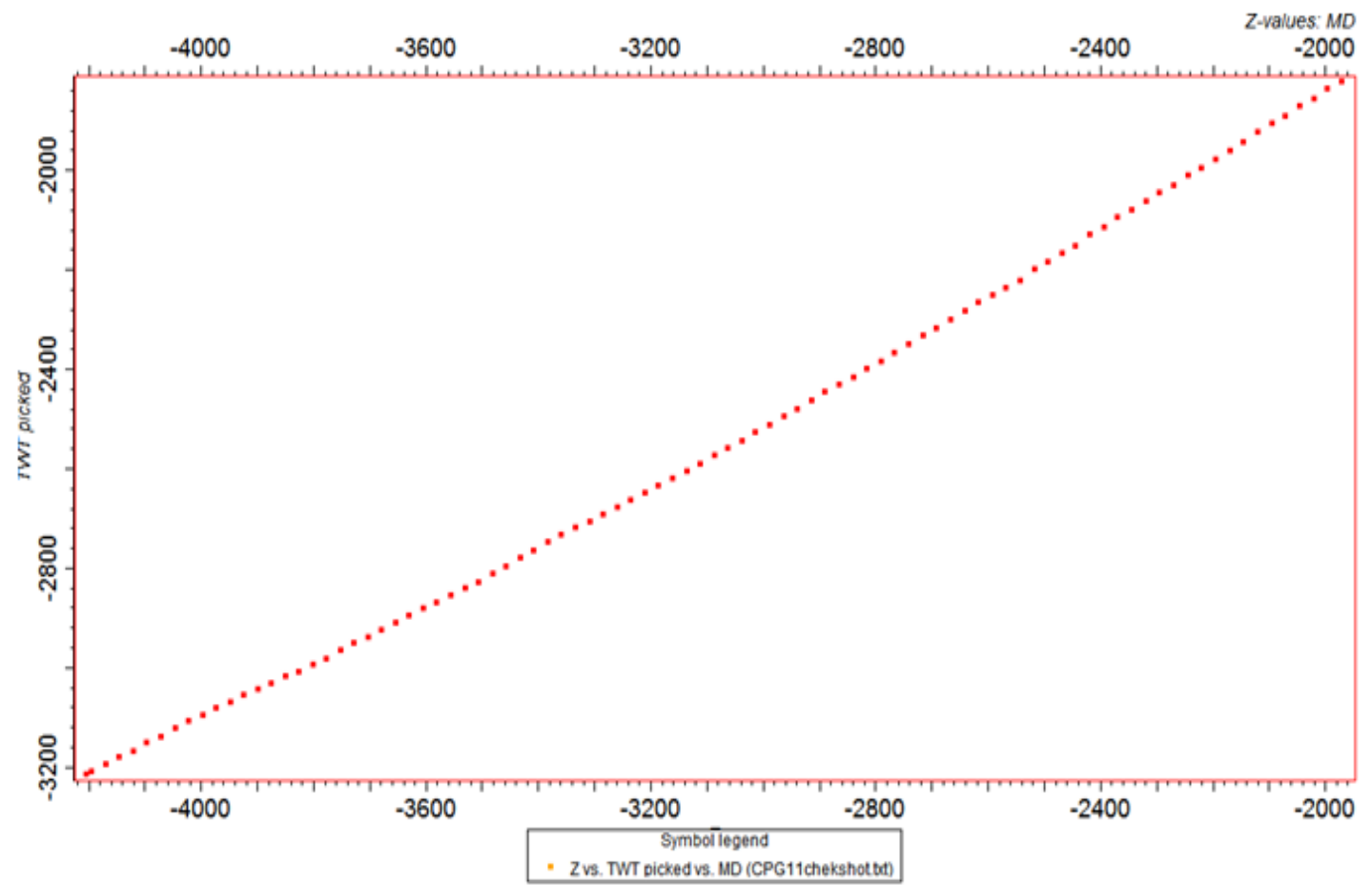

Fig. 5: TWT-Z Curve for D checkshot used for Depth Conversion

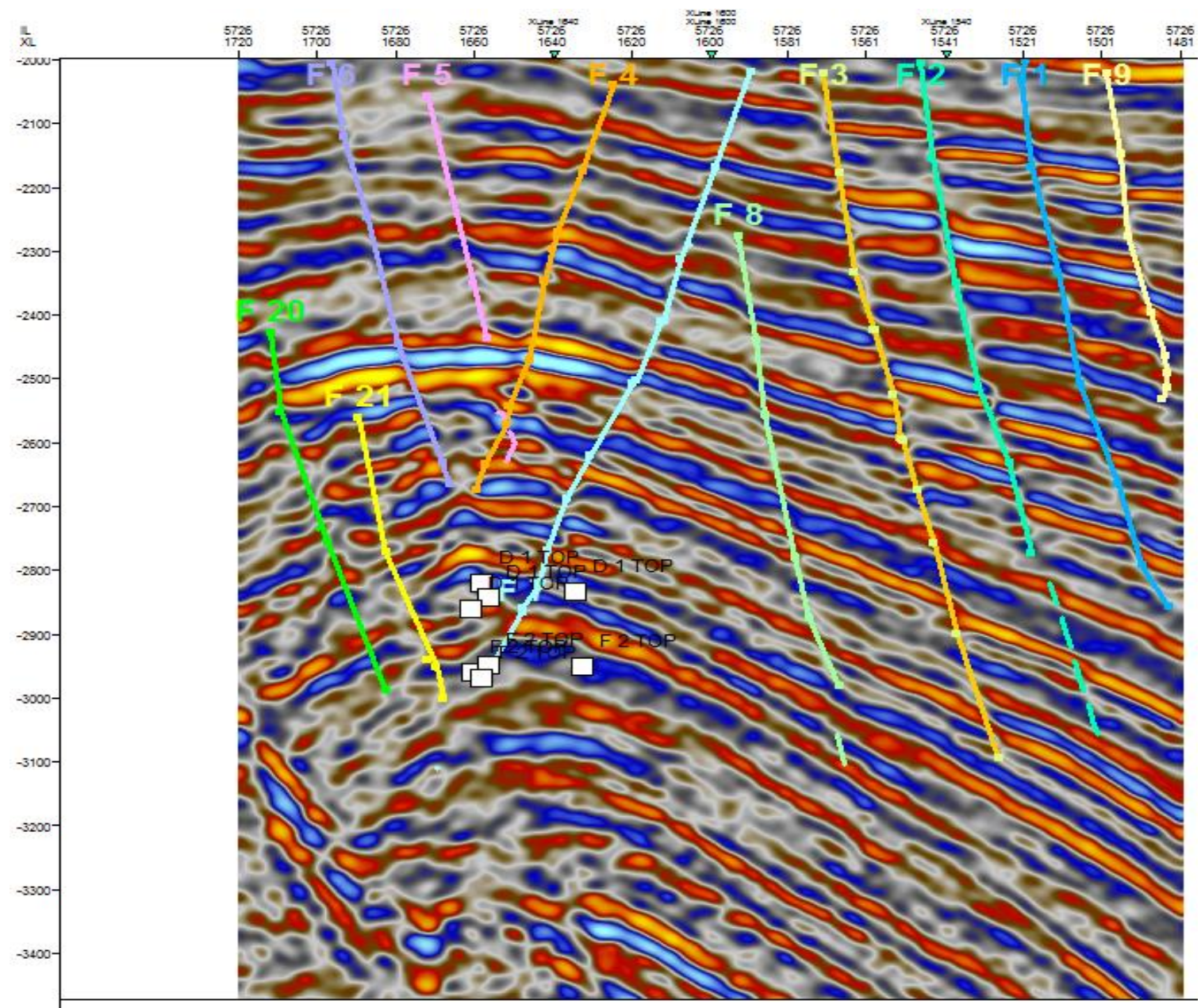

Fig. 6: Fault interpretation on Inline 
Application of Free Structural Model to Hydrocarbon Production Optimization in X Field, Niger.......

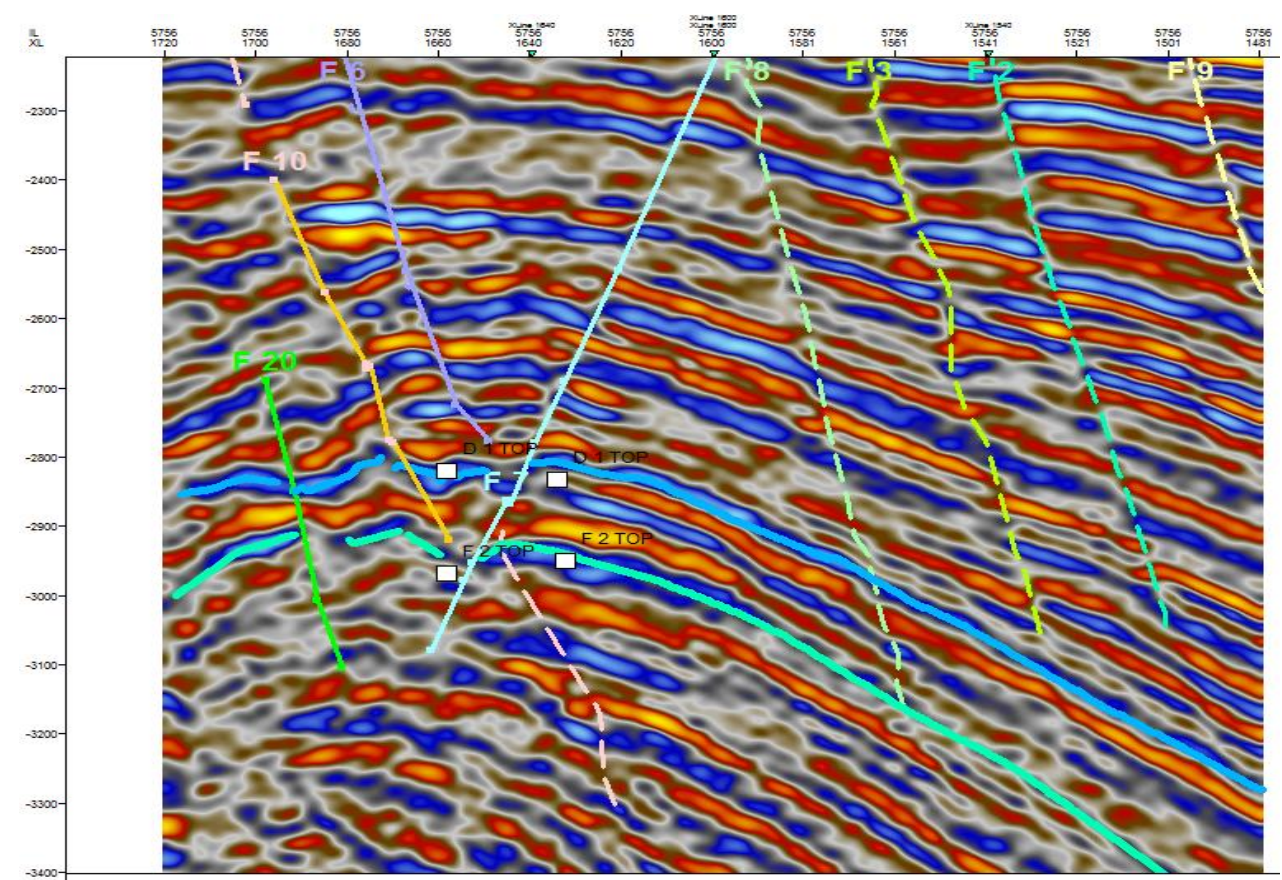

Fig. 7: Horizon interpretation on for reservoirs $D$ and $F$

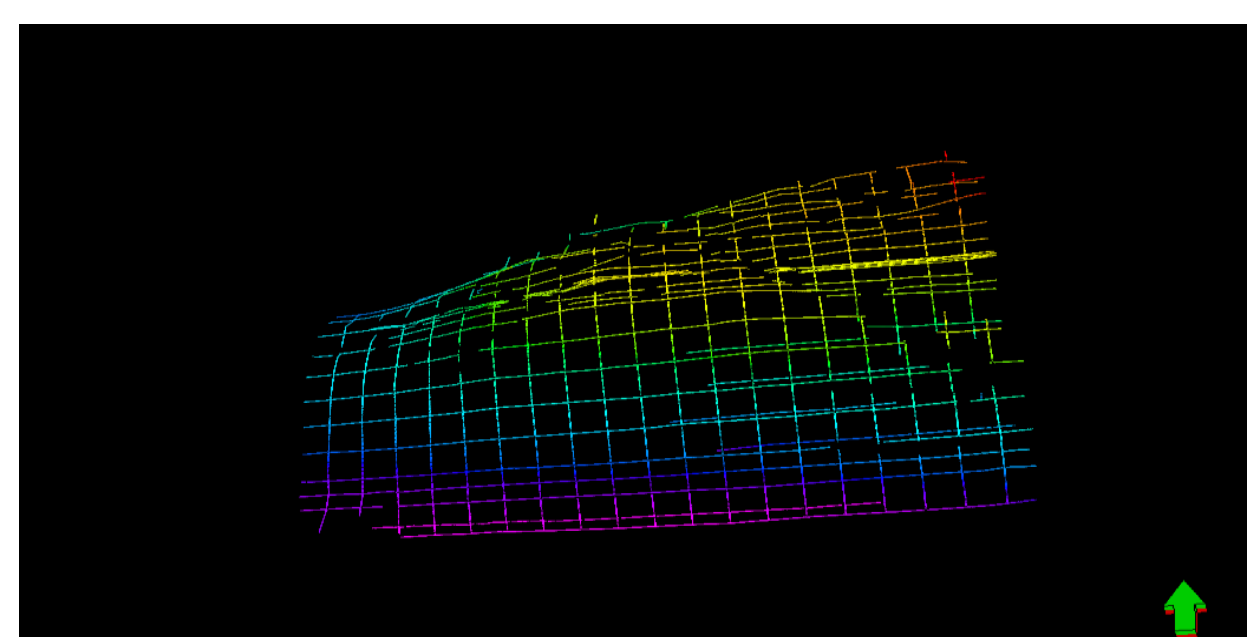

Fig. 8a: Interpreted horizon on reservoir D top



Fig. 8b: Interpreted horizon on reservoir F top 


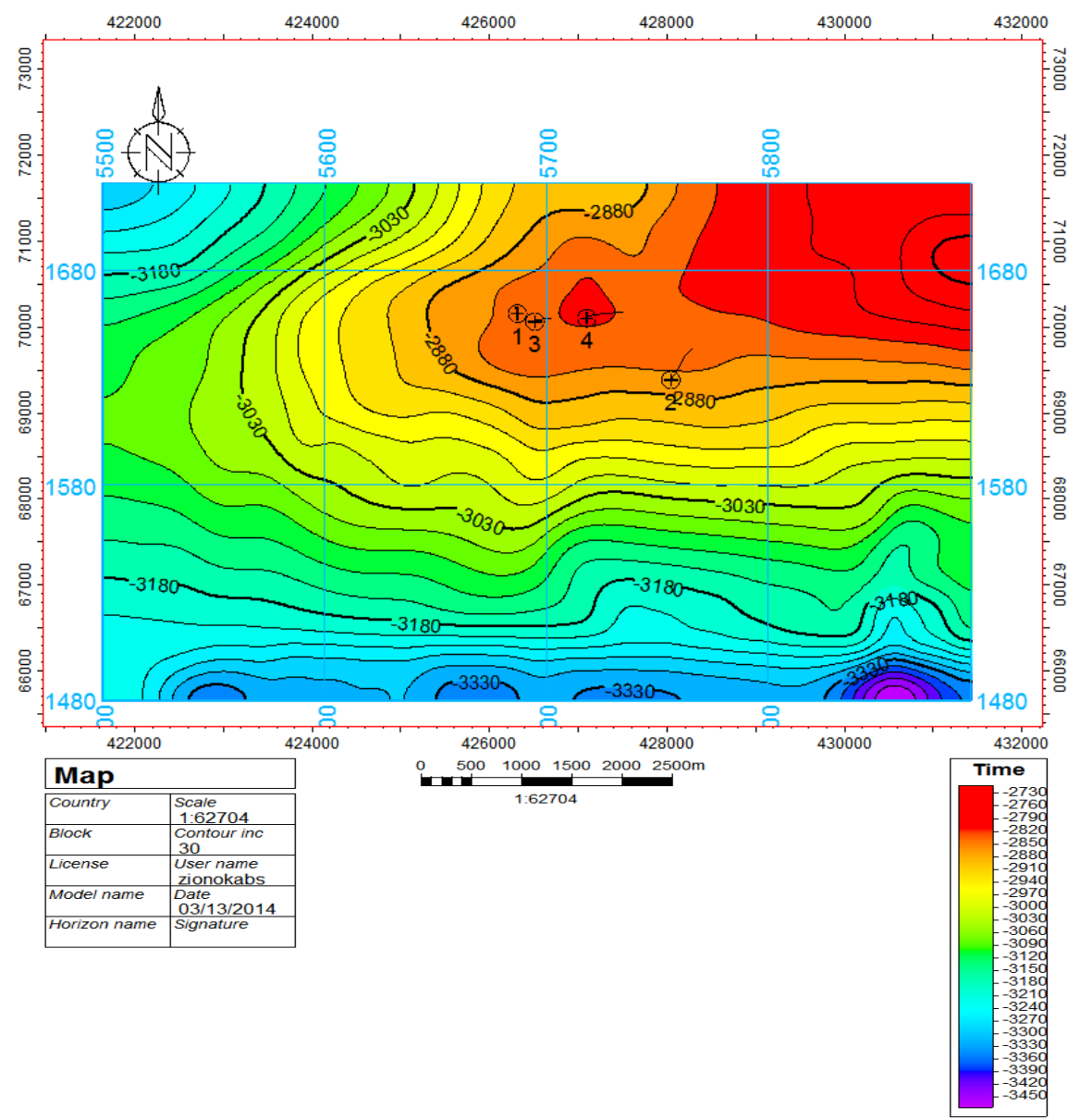

Fig. 9a: Time map of reservoir D

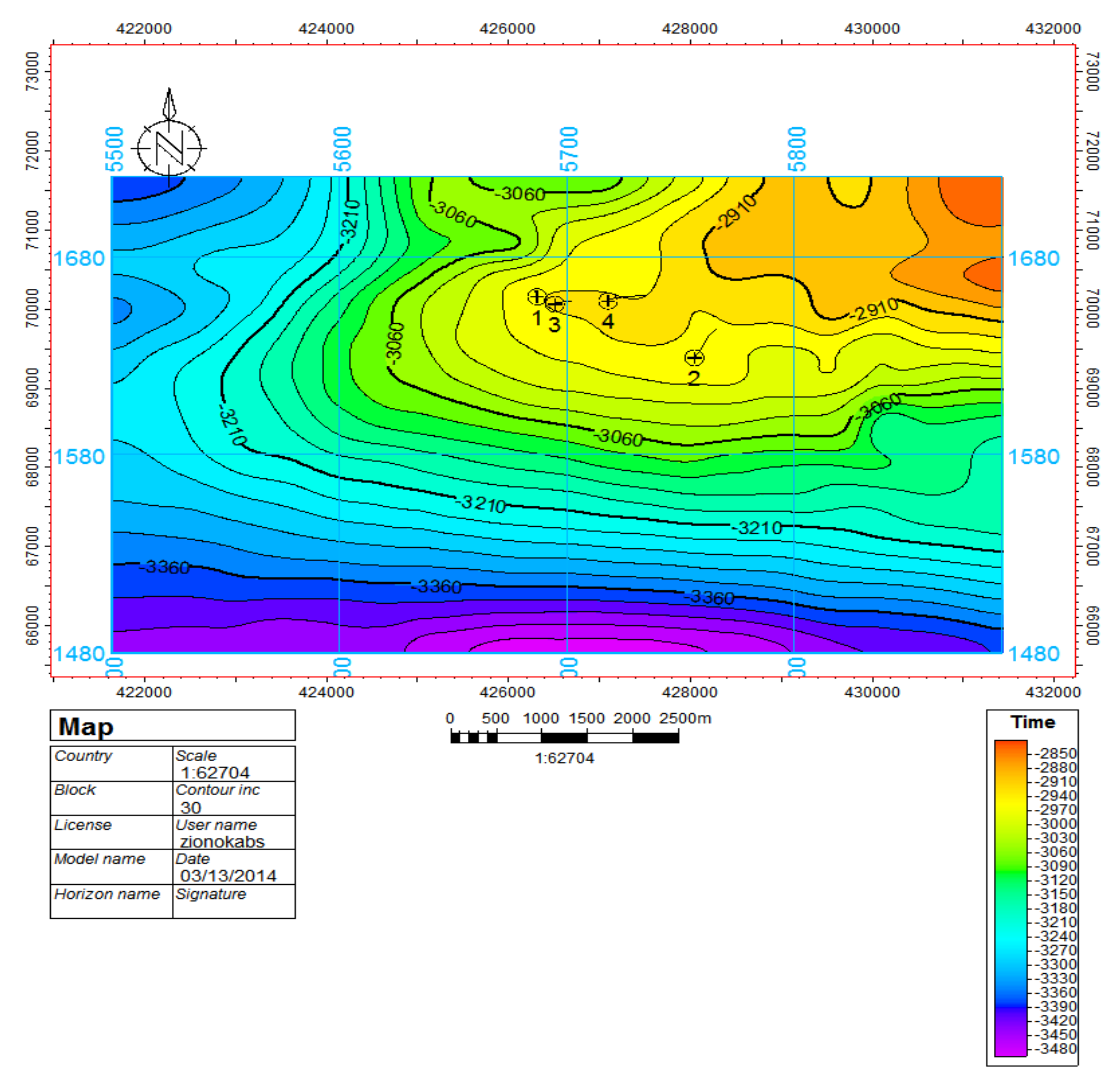

Fig. 9b: Time maps of reservoir F 




Fig. 10a: Depth map of reservoir D

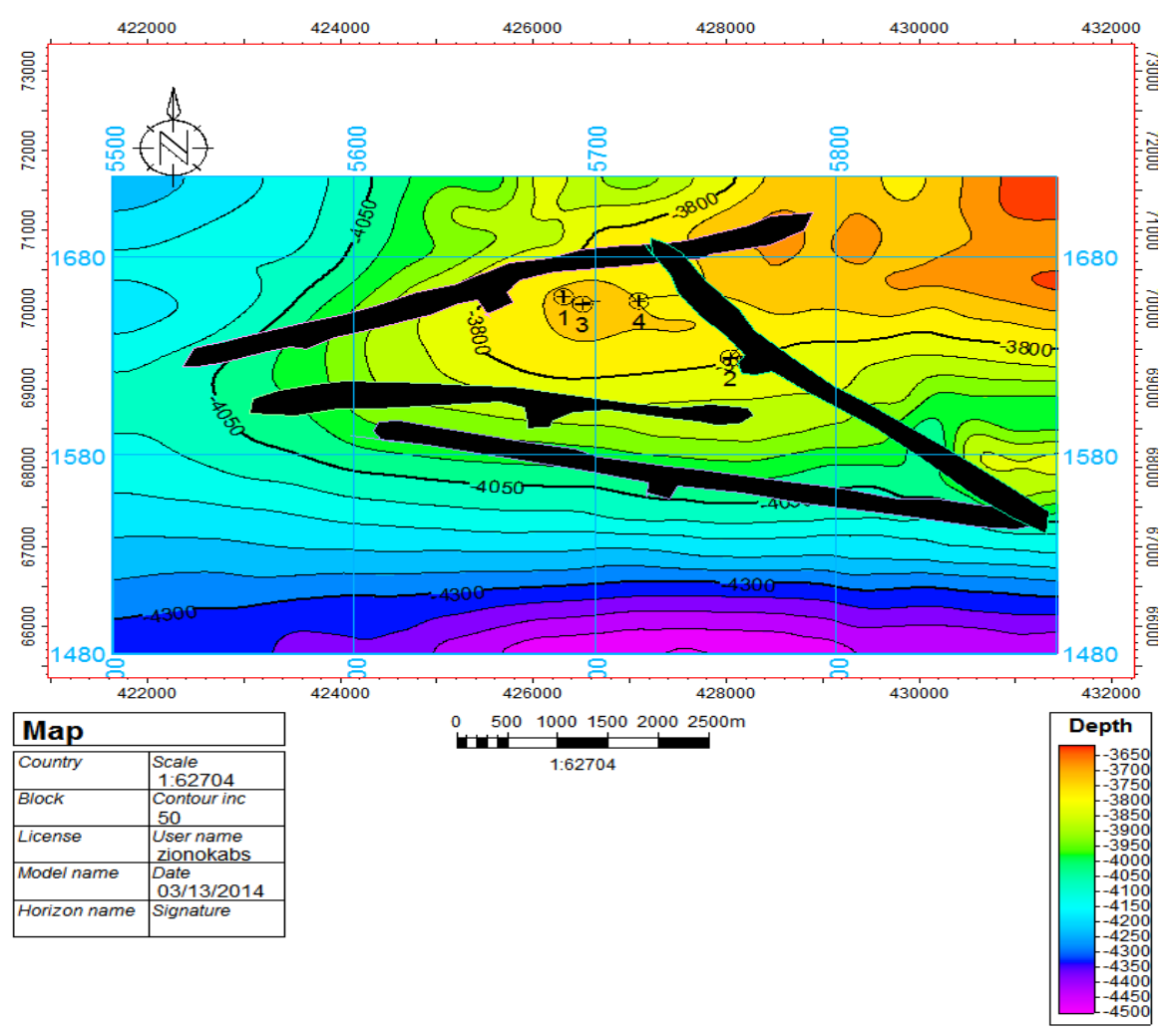

Fig. 10b: Depth map of reservoir $\mathrm{F}$ 


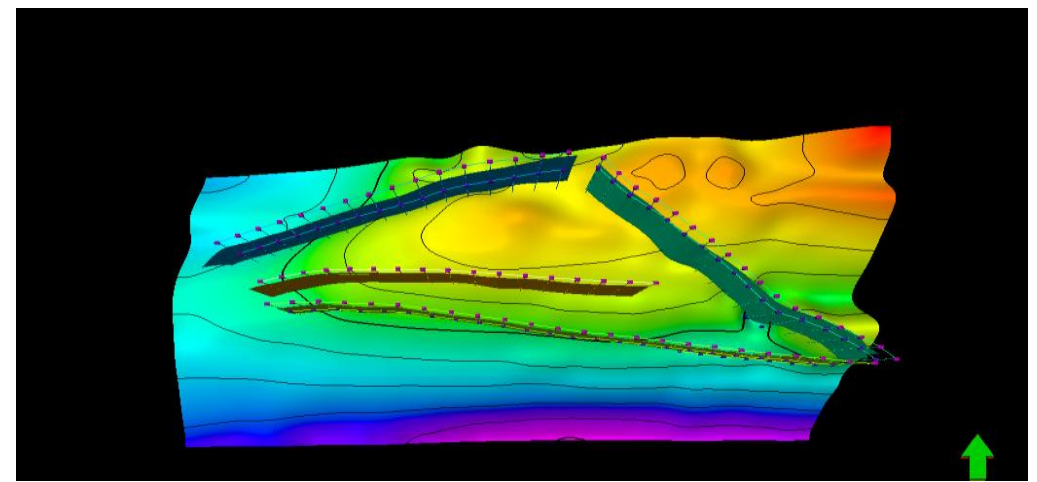

Fig. 11: Fault skeleton

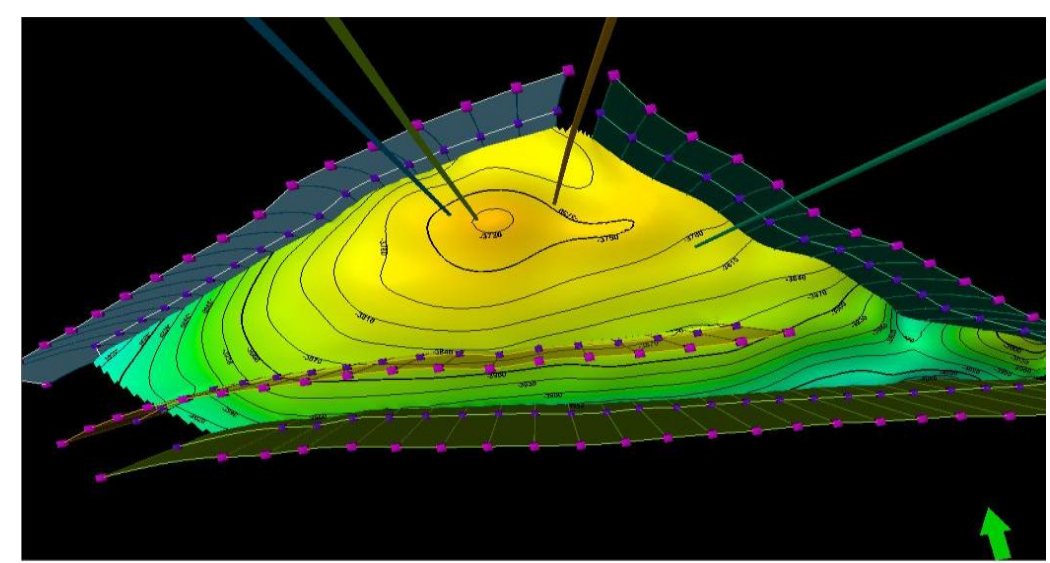

Fig. 12: 3D view of the Fault Models and Wells

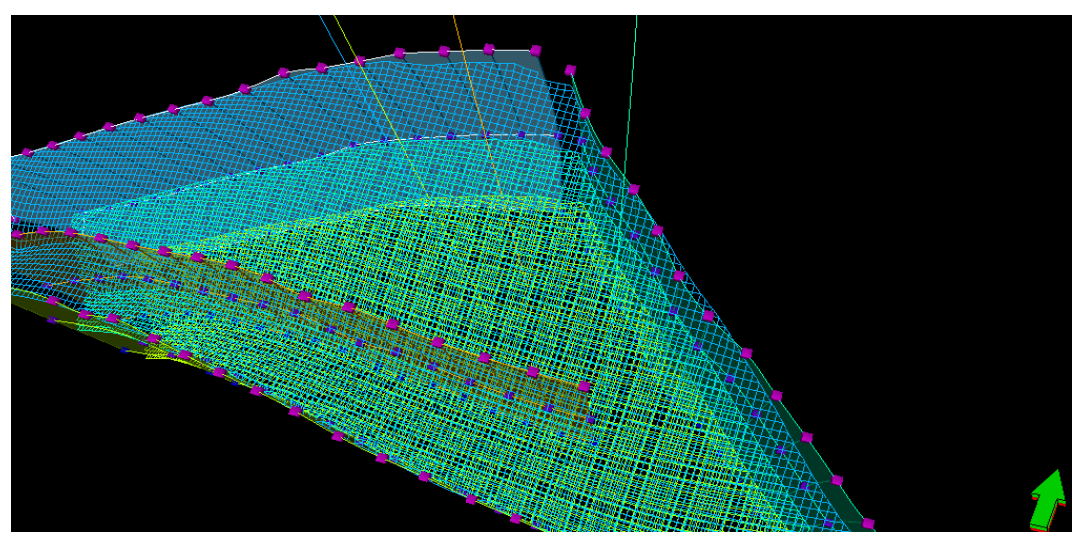

Fig. 13: 3D Grid and Wells

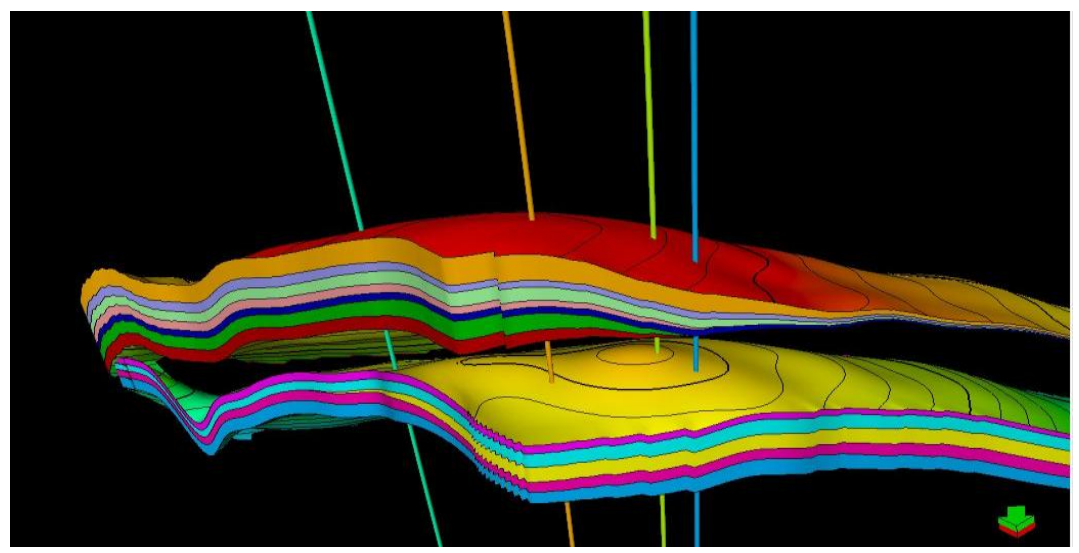

Fig. 14: Structural models of reservoirs $D$ and F stalked. 


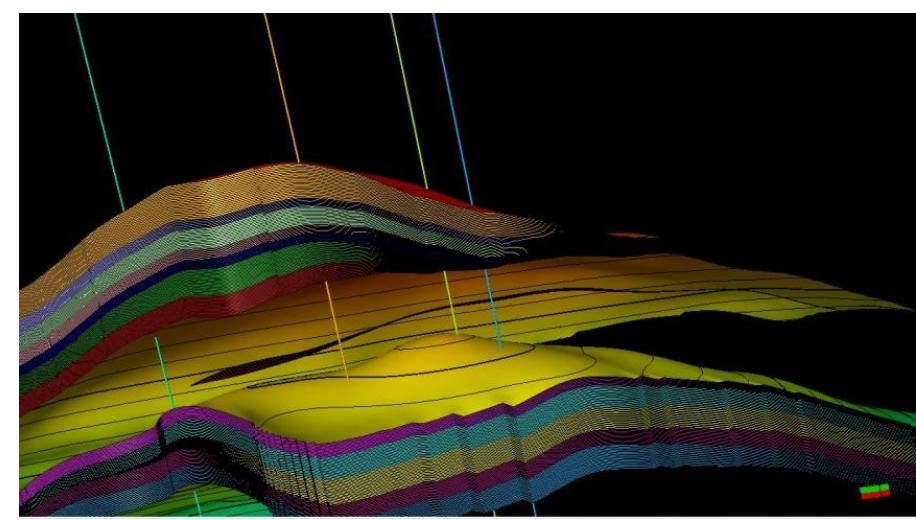

Fig. 15: Delineated zones in 3D view of the structural models.



Fig. 16: Delineated zones on the well section

\section{References}

[1] Ainsworth R.B (2006). Sequence stratigraphic-based analysis of reservoir connectivity: influence of sealing faults - a case study from a marginal marine depositional setting. Petroleum Geoscience, 12(2): 127-141. DOI: 1144/1354-079305-661.

[2] Ajakaiye, D.E and Bally, A.W. (2002): Some structural styles on reflection profiles from offshore Niger Delta. Serach and recovery article No. 10031 AAPG continuing Education course note series No. 41.

[3] Alao P.A, Olabode S.O, Opeloye S.A (2013): Integration of seismic and petrophysic to characterize reservoirs in "ALA" oil field, Niger Delta. Scientific WorldJournal, v. 2013, 1-15, DOI: 10.1155/2013/421720.eCollection 2013.

[4] Allen J.R.L(1965). Late Quaternary Niger Delta, and adjacent areas-sedimentary environment and lithofacies: AAPG Bulletin, 49, 547-600

[5] Biddle K.B and Wielchowsky C.C (1994). Hydrocarbon Traps, Exxon Exploration Company; Houston, Texas, U.S.A.

[6] Christopher Benetatos and DariorViberti (2010). Fully Integrated Hydrocarbon Reservoir Studies: Myth or Reality; American Journal of Applied Sciences 7 (11): 1477-1486, ISSN 1546-9239

[7] Doust H and Omatsola E (1990). Niger Delta, in Edwards, J. D, and Santogrossi, P.A,(Eds), Divergent/passive Margin Basins, AAPG Memoir 48, American Association of Petroleum Geologists, Tulsa, 239-248.

[8] Ekine A.S and Ibe A.A (2013).Delineation of Hydrocarbon bearing reservoirs from surface Seismic and Well Log Data (Nembe Creek) in Niger Delta Oil Field. IOSR Journal of Applied Physics (IOSR-JAP) e-ISSN: 2278-4861. 4(3): 26-30.

[9] Emujakporue, Godwin O and Ngwueke, Marcel L (2013).Structural interpretation of seismic data from XY Field, onshore Niger Delta, Nigeria. J. Appl. Sci. Environ. Manage, 17 (1): 153-158.

[10] Israel Cohen, Nicholas Coult and Anthony Vassiliou A (2006). Detection and extraction of fault surfaces in 3D seismic data: Geophysics, 71, 21-27.

[11] Jolley S.J, Fisher J and AinsworthR.B (2010). Reservoir compartmentalization: an introduction, Geological Society, London, Special Publications 2010, 347, 1-8

[12] Morgan L.B and Dow W.G (1994).The petroleum system from source to trap.AAPG Memoir 60.

[13] Oomkens E (1974). Lithofacies relations in late Quaternary Niger Delta complex: Sedimentology, 21, $195-222$. 